\section{Commentary: Therapeutic plasma exchange in COVID-19 pediatric patients: Is there a role?}

\author{
Rachel D. Vanderlaan, MD, PhD
}

COVID-19 infection in pediatric patients is variable, ranging from asymptomatic to a multisystem inflammatory syndrome characterized by elevated cytokines and hyperimmune response. In a small subset of pediatric COVID-19 patients, particularly those with complex medical conditions and important comorbidities, severe respiratory failure can occur with deadly consequences. In the literature, the experience of extracorporeal membrane oxygenation (ECMO) in pediatric patients with severe acute respiratory distress syndrome (ARDS) due to COVID is largely confined to case reports, with some larger US and UK studies capturing outcomes of subsets of pediatric patients with COVID-19 requiring ECMO; however, data surrounding their ECMO course are limited. ${ }^{1-4}$ In their case report, Kakuturu and colleagues ${ }^{5}$ describe the successful use of veno-veno ECMO and therapeutic plasma exchange (TPE) to break the cycle of cytokine storm, coagulopathy, and endothelial dysfunction in a morbidly obese teenager with ARDS attributed to COVID-19. In addition, they highlight a programmatic approach to ECMO recipients involving early extubation and ambulation.

TPE has shown some benefit in adult patients with severe sepsis and multisystem organ failure ${ }^{6}$ and has been applied to adult patients with fulminant COVID-19 infection as rescue therapy. ${ }^{7,8}$ TPE is hypothesized to break the cycle of coagulopathy, endothelial dysfunction, and cytokine storm that plays a role in adult COVID-19. Recently published studies show reductions in C-reactive protein, interleukin-6, lactate dehydrogenase, and D-dimer, in

\footnotetext{
From the Division of Cardiovascular Surgery, Hospital for Sick Children, Toronto, Ontario, Canada.

Disclosures: The author reported no conflicts of interest.

The Journal policy requires editors and reviewers to disclose conflicts of interest and to decline handling or reviewing manuscripts for which they may have a conflict of interest. The editors and reviewers of this article have no conflicts of interest.

Received for publication April 12, 2021; revisions received April 12, 2021; accepted for publication April 12, 2021; available ahead of print April 16, 2021.

Address for reprints: Rachel D. Vanderlaan, MD, PhD, Division of Cardiovascular Surgery, Hospital for Sick Children, 555 University Ave, Room 1525 Hill Wing, Toronto, Ontario, M5G 1X8 Canada (E-mail: Rachel.vanderlaan@ sickkids.ca). JTCVS Techniques 2021;7:267-8

2666-2507

Copyright (c) 2021 The Author(s). Published by Elsevier Inc. on behalf of The American Association for Thoracic Surgery. This is an open access article under the CC BY-NC-ND license (http://creativecommons.org/licenses/by-nc-nd/4.0/).

https://doi.org/10.1016/j.xjtc.2021.04.012
}

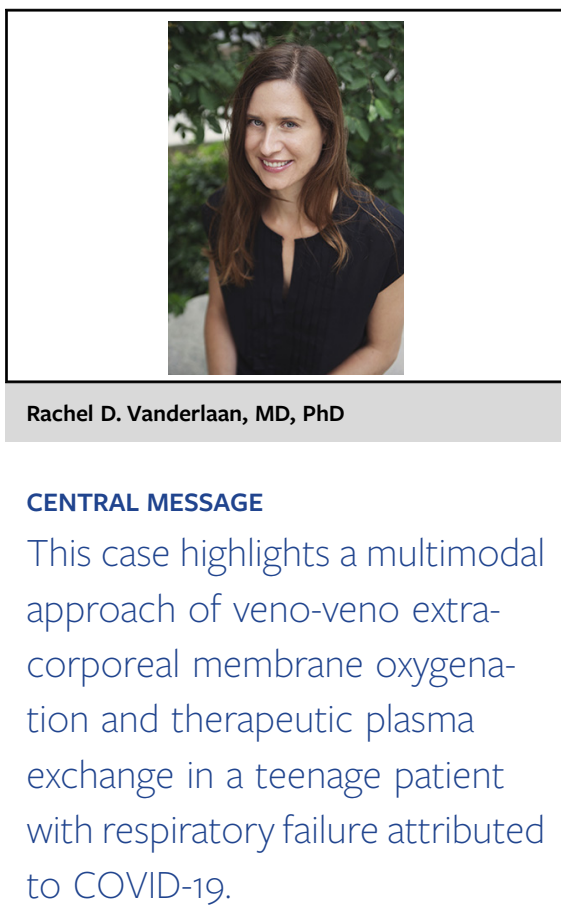

addition to improved oxygenation after TPE in critically ill COVID-19 adults. ${ }^{9,10}$ For patients with fulminant COVID-19 ARDS, TPE is emerging as a potential adjunct to the COVID -19 armamentarium; however, more research is needed to guide its potential use in adult patients.

There are no detailed reports of TPE in pediatric COVID19 patients and how adult data applies to the pediatric population with severe COVID-19 infection is unclear. TPE has been described as a rescue therapy during the H1N1 pandemic in pediatric patients. Three children with acute lung injury and hemodynamic compromise underwent TPE after failure of conventional therapy and saw improvement in oxygenation and vasopressor support. ${ }^{11}$ The report by Kakuturu and colleagues highlights the adjunct use of TPE and concomitant reduction in measured inflammatory markers, suggesting a temporal improvement related to TPE use.

This case report describes a 15 -year-old patient with many comorbidities found in adult COVID patients (obesity, prediabetes, hypertension), and the generalizability of these results to the broader pediatric population is not clear. However, Kakuturu and colleagues have provided important insights into care for this complex case with their successful use of veno-veno ECMO and TPE in a pediatric patient with severe ARDS attributed to COVID-19. Given the rare occurrence of severe SARS-CoV-2 in pediatric patient, multi-institutional discussions are needed to delineate a role of TPE in critically ill pediatric COVID-19 patients. 


\section{References}

1. Di Nardo M, Hoskote A, Thiruchelvam T, Lillie J, Horan M, Belda Hofheinz S, et al. Extracorporeal membrane oxygenation in children with coronavirus disease 2019: preliminary report from the Collaborative European Chapter of the Extracorporeal Life Support Organization Prospective Survey. ASAIO J. 2021;67: $121-4$.

2. Davies P, Evans C, Kanthimathinathan HK, Lillie J, Brierley J, Waters G, et al. Intensive care admissions of children with paediatric inflammatory multisystem syndrome temporally associated with SARS-CoV-2 (PIMS-TS) in the UK: a multicentre observational study. Lancet Child Adolesc Health. 2020;4:669-77.

3. Dufort EM, Koumans EH, Chow EJ, Rosenthal EM, Muse A, Rowlands J, et al. Multisystem inflammatory syndrome in children in New York State. $N$ Engl J Med. 2020;383:347-58.

4. Feldstein LR, Rose EB, Horwitz SM, Collins JP, Newhams MM, Son MBF, et al. Multisystem inflammatory syndrome in U.S. children and adolescents. $N$ Engl J Med. 2020;383:334-46.

5. Kakuturu J, McCluskey C, Casey FL III, Cicek S, Awori Hayanga JW. Extracorporeal membrane oxygenation to treat a 15 -year-old patient with severe coronavirus disease 2019 (COVID-19) respiratory failure. J Thorac Cardiovasc Surg Tech. 2021;7:265-6.
6. Busund R, Koukline V, Utrobin U, Nedashkovsky E. Plasmapheresis in severe sepsis and septic shock: a prospective, randomised, controlled trial. Intensive Care Med. 2002;28:1434-9.

7. Kamran SM, Mirza ZEH, Naseem A, Liaqat J, Fazal I, Alamgir W, et al. Therapeutic plasma exchange for coronavirus disease-2019 triggered cytokine release syndrome; a retrospective propensity-matched control study. PLoS One. 2021; 16:e 0244853 .

8. Keith P, Day M, Choe C, Perkins L, Moyer L, Hays E. The successful use of therapeutic plasma exchange for severe COVID-19 acute respiratory distress syndrome with multiple organ failure. SAGE Open Med Case Rep. June 18, 2020 [Epub ahead of print].

9. Morath C, Weigand MA, Zeier M, Speer C, Tiwari-Heckler S, Merle U. Plasma exchange in critically ill COVID-19 patients. Crit Care. 2020;24:481.

10. Gluck WL, Callahan SP, Brevetta RA, Stenbit AE, Smith WM, Martin JC, et al. Efficacy of therapeutic plasma exchange in the treatment of Penn class 3 and 4 cytokine release syndrome complicating COVID-19. Respir Med. 2020;175: 106188.

11. Patel P, Nandwani V, Vanchiere J, Conrad SA, Scott LK. Use of therapeutic plasma exchange as a rescue therapy in $2009 \mathrm{pH} 1 \mathrm{~N} 1$ influenza A-an associated respiratory failure and hemodynamic shock. Pediatr Crit Care Med. 2011;12:e87-9. 